\title{
Morpho-agronomy performance, seed nutrition content, and Aphis craccivora resistance of cowpea (Vigna unguiculata) genotypes
}

\author{
MUHAMAD GHAZI AGAM SAS ${ }^{1, \boldsymbol{v}}$, YUDIWANTI WAHYU ${ }^{2}$, MUHAMAD SYUKUR ${ }^{2}$, PURNAMA HIDAYAT ${ }^{3}$ \\ ${ }^{1}$ Program of Plant Breeding and Biotechnology, Graduate School, Institut Pertanian Bogor. Jl. Raya Dramaga. Bogor 16630, West Java, Indonesia. \\ Tel./fax.: +62-251-8629353, "email: agamghaziagam@apps.ipb.ac.id \\ ${ }^{2}$ Department of Agronomy and Horticulture, Faculty of Agriculture, Institut Pertanian Bogor. Jl. Meranti, Dramaga. Bogor 16630, West Java, Indonesia \\ ${ }^{3}$ Department of Plant Protection, Faculty of Agriculture, Institut Pertanian Bogor. Jl. Meranti, Dramaga. Bogor 16630, West Java, Indonesia
}

Manuscript received: 27 July 2021. Revision accepted: 23 September 2021.

\begin{abstract}
Sas MGA, Wahyu Y, Syukur M, Hidayat P. 2021. Morpho-agronomy performance, seed nutrition content, and Aphis craccivora resistance of cowpea (Vigna unguiculata) genotypes. Biodiversitas 22: 4320-4326. Cowpea (Vigna unguiculata subsp. unguiculata) is an agricultural commodity that can be a source of vegetable protein and replace the need for soy as a food ingredient. The wide adaptability under sub-optimum conditions placed cowpeas as the choice to be developed. This study aimed to evaluate the cowpea genotype's agronomic performance and resistance to Aphis craccivora to be proposed as superior genotypes. Observations were made on the morpho-agronomic characters, including the color of the young pods and dry seeds, the number of pods, the productivity of fresh pods and dried seeds, and the nutrition content. The resistance to Aphis craccivora was evaluated using a nochoice test whole plant for the resistance and tolerance evaluation. This study showed that the productivity of young pods (4.86-15.13 tons ha-1), dry seed productivity (0.83-2.71 tons ha-1). The protein content differed significantly among the 20 genotypes ranging from $19.24 \%$ to $24.45 \%$. Aphid infestation significantly inhibited plant growth compared with non-infested plants. Infestation of Aphis craccivora decreased the dry weight of the plant by about $20 \%$ to $70 \%$. Based on the aphid population, the 20 genotypes were classified into medium-high to very high aphid damage intensity.
\end{abstract}

Keywords: Agronomy, aphids, characterization, cowpeas, infestation

\section{INTRODUCTION}

Cowpea is a legume plant that can be used as fodder, forage, and biopharmaceutical (vaccine), and in the environmental study, it can be used as an erosion control plant and soil nutrient improvement. (Boukar et al. 2013). However, cowpea has not received particular attention to be developed. In contrast, it has the potential to answer the challenges of food and nutrition security and agricultural sustainability (Gomes et al. 2021). Furthermore, cowpea has a role in sustainable food security with its high content of phytonutrients and minerals, which are key in addressing malnutrition and hunger in Sub-Saharan Africa (Kirigia et al. 2018).

Cowpea is a potential agricultural commodity as a source of protein to replace soybeans (Budhi and Aminah 2010). The nutritional content of cowpea seeds has an average protein content of $27.4 \%$, fat $1.9 \%$, fiber $4.48 \%$, and Carbohydrates 48,53\% (Avanza et al. 2013). Cowpea is a source of protein that is pretty good (18-25\%) which is equivalent to certain types of meat (Narayana and Angamuthu 2021). Other than that, cowpeas are adaptable to drought conditions and grow in poor soils. However, they are sensitive to severe drought, especially during pod setting and grain filling stages (Horn and Shimelis 2020). Cowpea shows its adaptation to acid soil $(\mathrm{pH}=4.83)$ by producing $50 \%$ to $60 \%$ of seed weight from optimum conditions (Setyowati and Sutoro 2010). This makes cowpea very potential to be developed in the face of the challenges of global warming that may cause more widespread suboptimal land.

Challenges in cowpea cultivation are found 20 kinds of viruses reported to infect cowpea (Horn and Shimelis 2020). These viruses contribute to $90 \%$ yield losses (Mbeyagala et al. 2014). These diseases can be caused and transmitted through insect vectors, one of which is aphids. The Aphids that act as vectors of this virus are mostly aphids in the group Aphididae (James and Perry 2004). Control of disease vector pests is a good step in preventing disease virus transmission. One way to overcome the transmission of virus diseases is to use superior varieties assembled from two different parents (Sahid et al. 2020). The assembly of varieties resistant to disease vector pests can be carried out to control pest attacks and disease spread (Ehlers and Hall 1997). The use of insecticides in controlling aphids is difficult because these pests often become resistant to insecticides, so that the development of plants that are resistant to aphids is the best solution in sustainable agriculture (Deschamps et al. 2015). The use of plant varieties that are resistant to pest attacks is beneficial in optimizing the implementation of Integrated Pest Management (Daryanto et al. 2017).

This study aims to evaluate and obtain the performance information on morphological and agronomic character yield components, the nutritional content of cowpea genotypes, and resistance to pests A. craccivora, which can contribute to the assembly of new varieties. 


\section{MATERIALS AND METHODS}

\section{Genetic material}

The materials used in this study included genetic material from the Department of Agronomy and Horticulture, IPB, Indonesia, with 11 genotypes from pedigree selection (G1 to G11) and four parental genotypes (T1 to T2). In addition, five varieties from the Indonesian Legume and Tuber Crop Research Institute (Balitkabi), Malang, East Java, Indonesia, were also used as the check varieties ( $\mathrm{C} 1$ to $\mathrm{C} 5)$ (Table 1).

\section{Characterization of morpho-agronomic characters and nutrient content}

This research was conducted using a Completely Randomized Block Design (RKLT) with a single factor of 20 cowpea genotypes with three repetitions so that the experiment obtained 60 experimental units. Each experimental unit was planted in beds measuring $3 \times 1$ meter with a spacing of $50 \times 25 \mathrm{~cm}$, where $50 \mathrm{~cm}$ is the distance between rows in the bed and $25 \mathrm{~cm}$ is the distance between individual plants in a row so that we get 24 plants in each row experimental unit. Planting is done by planting one seed per planting hole. Embroidery is done at the age of 5-7 DAP. Essential fertilization is done by giving manure a dose of 20 tons ha-1, which is done before planting. Further fertilization was carried out by pouring $250 \mathrm{ml}$ of NPK 16-16-16 fertilizer at a dose of $5 \mathrm{~g} \mathrm{~L}-1$ in the growth phase and $10 \mathrm{~g} \mathrm{~L}-1$ in the development phase since entering the flowering stage. Pests and plant diseases were controlled mechanically and chemically using insecticides (Deltamethrin) with doses $2 \mathrm{~mL} \mathrm{~L}-1$ and fungicides (Mankozeb) with doses $2 \mathrm{~g} \mathrm{~L}-1$ when symptoms appeared. Harvesting is done by dividing two plots on each bed to harvest young and dry pods (seeds).

Table 1. Material genetic in this research

\begin{tabular}{|c|c|c|c|}
\hline $\begin{array}{c}\text { Geno- } \\
\text { type } \\
\text { code }\end{array}$ & Pedigree & Sources & Notes \\
\hline G1 & F4-002001-11-B & IPB & KM2 x KM1 \\
\hline $\mathrm{G} 2$ & F4-002TG2-5-1 & IPB & KM2 x TG2 \\
\hline G3 & F4-002TG2-5-2 & IPB & $\mathrm{KM} 2 \times \mathrm{TG} 2$ \\
\hline G4 & F6-002TG2-5-1-S & IPB & KM2 x TG2 \\
\hline G5 & F6-002004-8-1-B-3 & IPB & KM2 x KM4 \\
\hline G6 & F6-002TG2-5-3-2-S & IPB & KM2 x TG2 \\
\hline G7 & F6-002TG2-5-3-2-B & IPB & KM2 x TG2 \\
\hline G8 & F6-004002-7-B-9 & IPB & KM4 x KM2 \\
\hline G9 & КTH-2-2-2 & IPB & Screening from Yardlong \\
\hline G10 & КТH-2-5-11 & IPB & Screening from Yardlong \\
\hline G11 & КTH-2-6-1-9 & IPB & Screening from Yardlong \\
\hline $\mathrm{T} 1$ & KM-1 & IPB & Parent \\
\hline $\mathrm{T} 2$ & KM-2 & IPB & Parent \\
\hline T3 & KM-4 & IPB & Parent \\
\hline $\mathrm{T} 4$ & TG2 & IPB & Parent \\
\hline $\mathrm{C} 1$ & $\mathrm{KT}-1$ & Balitkabi & Check variety \\
\hline $\mathrm{C} 2$ & $\mathrm{KT}-4$ & Balitkabi & Check variety \\
\hline C3 & KT-5 & Balitkabi & Check variety \\
\hline $\mathrm{C} 4$ & KT-7 & Balitkabi & Check variety \\
\hline C5 & KT-9 & Balitkabi & Check variety \\
\hline
\end{tabular}

The evaluation was made on the morpho-agronomic characters, included plant height, number of branches, and yield components, including young pod color, dry seed color, pod length, pod width, number of seeds per pod, number of pods per plant, the weight of young pod per plot, weight of dry seed per plot, and proximate analysis of dry seed. Young pods and dry seeds production per plot was used to estimate plant productivity based on Himawati (2019) as follows:

Productivity $\left(\right.$ ton $\left.h a^{-1}\right)=\frac{10000}{\text { plot area }} x$ production per plot

Proximate analysis was carried out to determine the content in cowpeas in the form of water, ash, fat, protein, and crude fiber content expressed in percent. The material used was dry seeds for each test genotype as much as 30 grams with two repetitions (Duplo).

\section{Cowpea resistance to $A$. craccivora Infestation}

Observation of the resistance character was carried out using the antibiosis test method and evaluation of plant tolerance based on the shrinkage of the agronomic character. The test genotypes were planted in pots containing planting media (cocopeat: manure) with a ratio of 1 : 1 by maintaining one seed per pot. All plants were arranged in the Greenhouse with a Completely Randomized Group Design (RKLT) research design with a treatment factor of a duration of infestation consisting of control (without $A$. craccivora infestation) five days. Infestations $A$. craccivora did at age 14 HST plant that is when the leaves trifoliate first it appears to do infestation $A$. craccivora as many as five birds in adult apterous phase for each plant.

The infestation method used is the no-choice test antibiosis method based on Deschamps et al. (2015), namely by infesting $A$. craccivora on each plant for each genotype and confinement for each plant, so that $A$. craccivora can only grow and develop under certain plant conditions and avoid contamination from outside.

Severity assessment criteria refer to the research of Daryanto et al. (2017), who selected the level of plant resistance to aphids to attack using the following selection criteria for the number of aphids, (i) very low: 8-21 aphids, (ii) low: 22-35 aphids, (iii) low medium: 36-49 aphids, (iv) medium: 50-63 aphids, (v) medium-high: 64-77 aphids, (vi) high: 78-91 aphids, and (vii) very high: 92-105.

The tolerance of cowpea genotype was evaluated by comparing the dry weight of $A$. craccivora infested plants with control plants. The tolerance level is measured based on the percentage of plant dry weight loss using the following calculation formula:

$$
\text { Dryweight loss }(\%)=\frac{(W 1-W 2)}{W 1} \times 100 \%
$$

Where: W1 is the dry weight of control plants (without infestation) (g), and W2 is the dry weight of plants infested with A. craccivora (g) (Laamari et al. 2008; Deschamps et al. 2015). 


\section{Data analysis}

Data analysis was carried out on morphological and agronomic parameters. The data obtained were tested using analysis of variance (ANOVA) with a significance level of $5 \%$. Significantly different variables were further tested using the HSD test using STAR software.

\section{RESULTS AND DISCUSSION}

\section{Morpho-agronomy character}

The cowpea genotypes test consists of 11 genotypes generated from crosses, four genotype elders, and five varieties of young morphology pods, as shown in Figure 1. The diversity of cowpea's young pods consists of the light green color spectrum, red to purple. In contrast, the color of dry seeds consists of a spectrum of white/beige, light brown, reddish-brown, maroon, to black, followed by a color pattern for genotypes that have two seed coat colors.

Based on the color of the pods, most of the test genotypes had the color of young green pods that were commonly consumed, while the genotypes F4-002TG2-5-1 (G2), F6-002TG2-5-3-2-B (G7), KTH-2-2 -2 (G9), KTH-25-11 (G10), and KTH-2-6-1-9 (G11) have purplish red to purple pods. The color of the cowpea seeds is the main character that needs to be evaluated because the color of the seeds can determine the direction of utilization of the genotype. Genotype F6-002004-8-1-B-3 (G5) has a unique seed color character, which has a white/beige seed coat color that can be developed as a raw material for making soybean substitute tempeh.

Anova results showed significant differences among genotypes on the observed pod and seed characters, as shown in the Post hoc HSD Test Tabel 2. Genotypes T3 and $\mathrm{T} 1 \mathrm{had}$ the highest number of branches, 5.90 branches and 5.73 branches, respectively. Meanwhile, the advanced generation of the crosses genotypes had a mean value below both parents (Table 2). According to Srinivas et al. (2017), the number of branches on cowpea plants has a positive correlation with yield characters such as weight of 100 seeds $(r=0.722)$ and average pod weight $(r=0.759)$. This is supported by Chaudhary et al. (2020) that the number of branches per plant has a substantial direct correlation to the yield component $(r=0.6779)$ and is classified as a moderate heritability character (h2 = $59.28 \%$ ).

In the pod length variable, the genotypes of the crosses showed improvement in character values. Genotypes G7 (F6-002TG2-5-3-2-B), G2 (F4-002TG2-5-1), and G9 (KTH-2-2-2) had a higher mean pod length than the parents and varieties check. While the variable number of seeds per pod, the test genotypes and the parents of the cross had a lower mean value than the comparison varieties. The productivity of young pods from 20 genotypes showed that the F4-002001-11-B (G1) genotype gave the highest yield potential with 15.13 tons per hectare, followed by KM-2 and F6-002004-8-1-B-3 (G5) with potential yields of 11.44 and 10.96 tons per hectare, respectively. The productivity of dry beans in this study ranged from 0.83 tons ha-1 (G9, KTH 2-2-2) to 2.71 tons ha-1 (T1, KM-1), as was the case with the study of Nkhoma et al. (2020), the tested genotype used had average dry seed productivity of 0.75 tons ha- 1 with the best genotype, CP411 having a yield potential of 2.19 tons ha-1. Based on Himawati's research (2019) which conducted a preliminary yield test on several cowpea genotypes, it showed higher yield potential in genotypes KM-1, F4 KM2xKM1-11, F4 KM2xKM4-8-1, and KM-4, which ranged from $3.20-5.99$ tons/ha due to the use of broader spacing. Based on Balitkabi (2016), it is known that the range of potential yields of soybean varieties that have been released ranges from 1.22 to 3.82 tons/ha. This shows that the high productivity of some cowpea genotypes can be developed as an alternative food commodity.

\section{Nutrient content of cowpea genotype}

Based on the proximate analysis of dry seeds of 20 genotypes, analysis of variance was carried out. The results obtained were significantly different at the $5 \%$ significance level, as presented in Table 3. Based on Table 3, it can be seen that the protein content in the 20 tested genotypes ranged from $19.24 \%$ (G8, F6-004002-7-B-9) to $24.45 \%$ (C4, KT-7). Genotype F4-002001-11-B (G8) (24.29\%) had better protein content than its parents, namely KM-2 (T2) $(20.81 \%)$ and KM-1 (T1) (20.91\%). The genotypes F6002TG2-5-1-S (G4) and F4-002TG2-5-2 (G3) had a higher protein content of $23.48 \%$ and $23.02 \%$, respectively, the parental genotypes, KM-2. (T2) and TG-2 (T4). In addition, genotypes F4-020001-11-B (G1), F6-002TG2-51-S (G4), and F4-002TG2-5-2 (G3) were superior to the comparison variety KT-1 (C1), KT-4 (C2), and KT-9 (C5).

Although the protein content of cowpeas is lower than that of soybeans, with a protein content range of $35-47 \%$ dry weight (Ginting et al. 2009), cowpeas are a fairly good source of protein (18-25\%) (Narayana and Angamuthu 2021). In addition, the low-fat content (about 1.3\%) indicates that cowpea has a relatively better seed storage potential (Trustinah 2015).

\section{Cowpea resistance to $A$. craccivora infestation}

Based on Table 4 shows the genotypes that have a less severity at 5 days of infestation, namely, TG-2 (8.83\%), F6-002TG2-5-1-S (11.06\%), KTH 2-5- 11 (21.33\%), KT-5 (21.63\%), F4-002TG2-5-1 (22.87\%), F6-002004-8-1-B-3 (26.61\%), and F6-040002-7-B-9 (27.81\%) with a damage rate of below 30\%. The parental genotype TG-2 (T4) showed the lowest number of aphids with 67.00 aphids. Furthermore, G4 (F6-002TG2-5-1-S) had an amount of aphids about 112 aphids, but they had percentage decreases of dry weight only $11,06 \%$. 


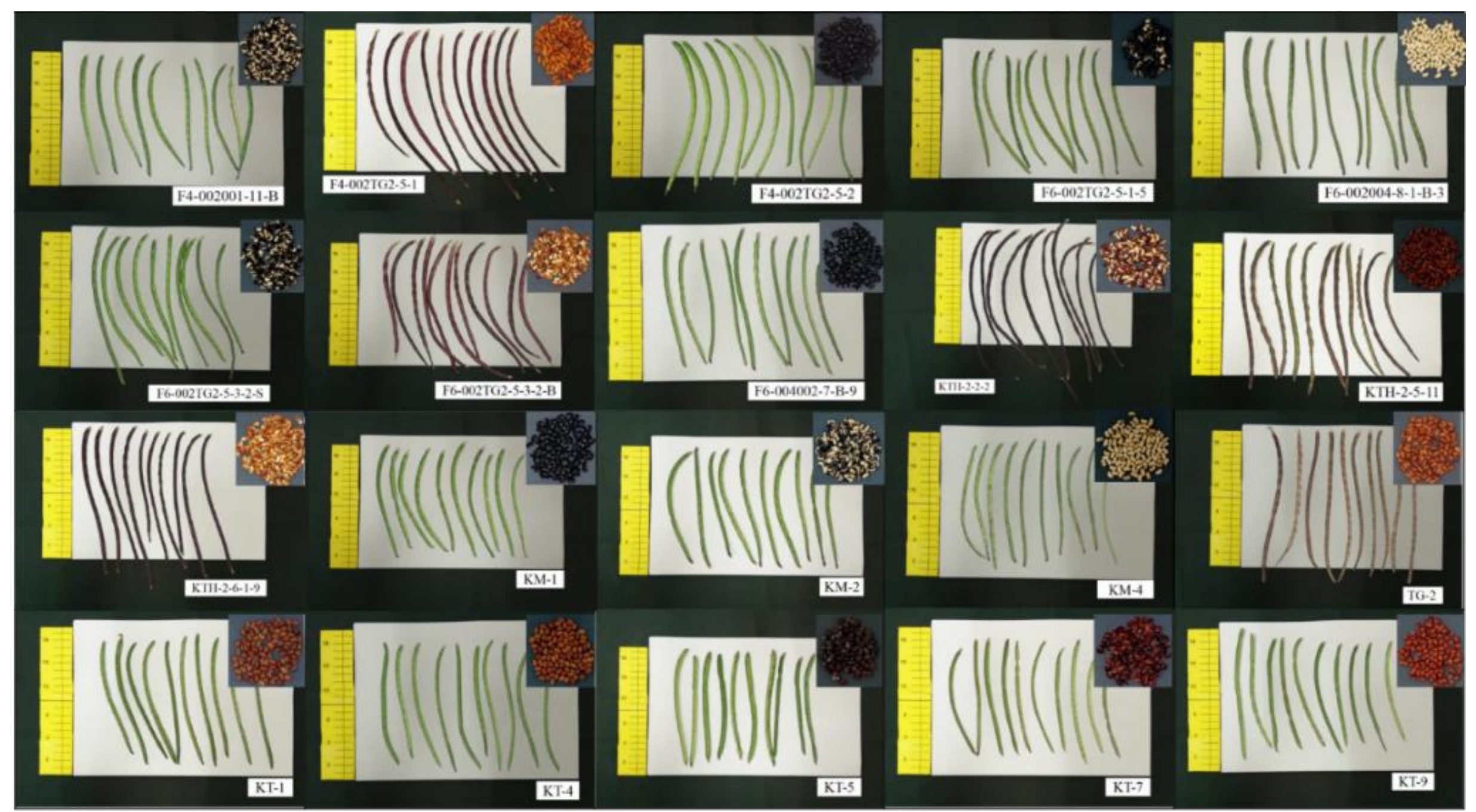

Figure 1. Morphology traits of young pods and dry seeds of 20 cowpea genotypes 
Table 2. The performance of the 20 genotypes of cowpea agronomic characters

\begin{tabular}{|c|c|c|c|c|c|c|c|}
\hline Genotype & $\begin{array}{c}\text { NB } \\
\text { (branches) }\end{array}$ & $\begin{array}{c}\text { PH } \\
(\mathbf{c m})\end{array}$ & $\begin{array}{c}\text { PL } \\
(\mathbf{c m})\end{array}$ & $\begin{array}{c}\text { NSP } \\
\text { (seed) }\end{array}$ & $\begin{array}{c}\text { NP } \\
\text { (pods) }\end{array}$ & $\begin{array}{c}\text { PProd } \\
\text { (ton ha-1) }\end{array}$ & $\begin{array}{c}\text { SProd } \\
\text { (ton ha-1) }\end{array}$ \\
\hline G1 & $5.43^{\mathrm{b}}$ & $44.33^{\mathrm{c}-\mathrm{f}}$ & $20.42^{\mathrm{d}}$ & $14.83^{\mathrm{e}-\mathrm{g}}$ & $27.27^{a b}$ & $15.13^{\mathrm{a}}$ & $2.38^{\mathrm{ab}}$ \\
\hline $\mathrm{G} 2$ & $4.47^{\mathrm{ef}}$ & $83.67^{\mathrm{a}}$ & $25.36^{\mathrm{a}}$ & $15.57^{\mathrm{d}-\mathrm{f}}$ & $15.08^{\mathrm{f}-\mathrm{h}}$ & $8.38^{\mathrm{b}-\mathrm{e}}$ & $1.47^{\mathrm{b}-\mathrm{d}}$ \\
\hline G3 & $4.27^{\mathrm{e}-\mathrm{h}}$ & $56.00^{\mathrm{bc}}$ & $20.63^{\mathrm{d}}$ & $14.20^{\mathrm{g}-\mathrm{i}}$ & $11.28^{\mathrm{h}}$ & $5.40^{\mathrm{de}}$ & $1.71^{\mathrm{a}-\mathrm{d}}$ \\
\hline G4 & $4.40^{\mathrm{e}-\mathrm{g}}$ & $44.33^{\mathrm{c}-\mathrm{f}}$ & $19.69^{\text {de }}$ & $14.67^{\mathrm{f}-\mathrm{h}}$ & $14.18^{\mathrm{f}-\mathrm{h}}$ & $5.15^{\mathrm{de}}$ & $1.98^{\mathrm{a}-\mathrm{d}}$ \\
\hline G5 & $4.80^{\mathrm{d}}$ & $56.33^{\mathrm{bc}}$ & $18.68^{\mathrm{ef}}$ & $14.23^{\mathrm{g}-\mathrm{i}}$ & $23.28^{b-d}$ & $10.96^{\mathrm{b}}$ & $2.55^{\mathrm{ab}}$ \\
\hline G6 & $4.53^{\mathrm{de}}$ & $46.00^{\mathrm{c}-\mathrm{f}}$ & $23.71^{\mathrm{b}}$ & $16.07^{a-d}$ & $18.45^{\mathrm{d}-\mathrm{f}}$ & $10.55^{\mathrm{bc}}$ & $2.27^{\mathrm{a}-\mathrm{c}}$ \\
\hline G7 & $4.53^{\mathrm{de}}$ & $54.67^{b-d}$ & $25.86^{\mathrm{a}}$ & $16.27^{\mathrm{b}-\mathrm{d}}$ & $14.49^{\mathrm{f}-\mathrm{h}}$ & $8.70^{b-d}$ & $1.71^{\mathrm{a}-\mathrm{d}}$ \\
\hline G8 & $5.67^{\mathrm{ab}}$ & $49.33^{\mathrm{b}-\mathrm{e}}$ & $17.45^{\mathrm{g}}$ & $14.13^{\mathrm{g}-\mathrm{i}}$ & $25.92^{a-c}$ & $8.28^{\mathrm{b}-\mathrm{e}}$ & $2.12^{\mathrm{a}-\mathrm{c}}$ \\
\hline G9 & $4.07^{\mathrm{h}}$ & $44.67^{\mathrm{c}-\mathrm{f}}$ & $24.85^{\mathrm{a}}$ & $13.70^{\mathrm{hi}}$ & $11.33^{\mathrm{h}}$ & $7.22^{\mathrm{c}-\mathrm{e}}$ & $0.83^{\mathrm{d}}$ \\
\hline G10 & $4.20^{\mathrm{f}-\mathrm{h}}$ & $38.33^{\mathrm{e}-\mathrm{g}}$ & $20.40^{\mathrm{d}}$ & $13.70^{\mathrm{hi}}$ & $16.33^{\mathrm{fg}}$ & $8.69^{b-d}$ & $1.48^{\mathrm{b}-\mathrm{d}}$ \\
\hline G11 & $4.17^{\mathrm{gh}}$ & $53.67^{b-d}$ & $22.46^{\mathrm{c}}$ & $15.97^{\mathrm{b}-\mathrm{d}}$ & $16.79^{\mathrm{fg}}$ & $8.47^{b-d}$ & $1.51^{\mathrm{b}-\mathrm{d}}$ \\
\hline $\mathrm{T} 1$ & $5.73^{\mathrm{a}}$ & $63.67^{\mathrm{b}}$ & $18.38^{\mathrm{fg}}$ & $13.37^{\mathrm{i}}$ & $21.97^{\mathrm{c}-\mathrm{e}}$ & $8.60^{b-d}$ & $2.71^{\mathrm{a}}$ \\
\hline $\mathrm{T} 2$ & $5.13^{\mathrm{c}}$ & $32.33^{\mathrm{fg}}$ & $19.65^{\text {de }}$ & $14.50^{\text {gh }}$ & $30.14^{\mathrm{a}}$ & $11.44^{\mathrm{b}}$ & $2.04^{\mathrm{a}-\mathrm{c}}$ \\
\hline $\mathrm{T} 3$ & $5.90^{\mathrm{a}}$ & $50.67^{\mathrm{b}-\mathrm{e}}$ & $18.19^{\mathrm{fg}}$ & $14.33^{\mathrm{g}-\mathrm{i}}$ & $28.44^{\mathrm{a}}$ & $11.75^{\mathrm{ab}}$ & $2.47^{\mathrm{ab}}$ \\
\hline $\mathrm{T} 4$ & $4.40^{\mathrm{e}-\mathrm{g}}$ & $26.33^{\mathrm{g}}$ & $23.09^{\mathrm{bc}}$ & $16.83^{\mathrm{ab}}$ & $10.44^{\mathrm{h}}$ & $6.29^{\mathrm{de}}$ & $1.10^{\mathrm{cd}}$ \\
\hline $\mathrm{C} 1$ & $5.77^{\mathrm{a}}$ & $36.67^{e-g}$ & $18.49^{\mathrm{fg}}$ & $17.17^{\mathrm{a}}$ & $18.28^{\mathrm{d}-\mathrm{g}}$ & $6.47^{\mathrm{de}}$ & $2.05^{\mathrm{a}-\mathrm{c}}$ \\
\hline $\mathrm{C} 2$ & $5.93^{\mathrm{a}}$ & $41.00^{\mathrm{d}-\mathrm{f}}$ & $18.83^{\mathrm{ef}}$ & $16.57^{\mathrm{a}-\mathrm{c}}$ & $17.11^{\mathrm{e}-\mathrm{g}}$ & $6.49^{\mathrm{de}}$ & $2.14^{\mathrm{a}-\mathrm{c}}$ \\
\hline $\mathrm{C} 3$ & $4.07^{\mathrm{h}}$ & $44.33^{\mathrm{c}-\mathrm{f}}$ & $16.24^{\mathrm{h}}$ & $16.10^{\mathrm{b}-\mathrm{d}}$ & $13.40^{\mathrm{gh}}$ & $4.86^{\mathrm{e}}$ & $1.70^{\mathrm{a}-\mathrm{d}}$ \\
\hline $\mathrm{C} 4$ & $4.33^{\mathrm{e}-\mathrm{h}}$ & $43.67^{\mathrm{c}-\mathrm{f}}$ & $16.29^{\mathrm{h}}$ & $15.73^{c-e}$ & $16.64^{\mathrm{fg}}$ & $6.40^{\mathrm{de}}$ & $1.60^{\mathrm{a}-\mathrm{d}}$ \\
\hline C5 & $4.77^{\mathrm{d}}$ & $45.33^{\mathrm{c}-\mathrm{f}}$ & $20.16^{\mathrm{d}}$ & $15.57^{\mathrm{d}-\mathrm{f}}$ & $14.13^{\mathrm{f}-\mathrm{h}}$ & $6.13^{\text {de }}$ & $1.12^{\mathrm{cd}}$ \\
\hline $\mathrm{CV}(\%)$ & 1.80 & 9.88 & 1.64 & 2.10 & 8.82 & 14.06 & 20.51 \\
\hline
\end{tabular}

Note: The numbers in the same column followed by the same letter are not significantly different in the HSD Test at a significant level of 5\%, NB: number of branches, PH: plant height, PL: pod length. NSP: number seed per pod, NP: number pods per plant, PProd: pod productivity, SProd: seeds productivity

Table 3. Nutrient content of 20 cowpea genotypes

\begin{tabular}{lccccc}
\hline \multirow{2}{*}{ Genotype } & \multicolumn{5}{c}{ \% Contents } \\
\cline { 2 - 6 } & Moistures & Ash & Fat & Protein & $\begin{array}{c}\text { Crude } \\
\text { fiber }\end{array}$ \\
\hline G1 & $18.47^{\mathrm{ab}}$ & $4.41^{\mathrm{a}-\mathrm{c}}$ & 0.76 & $24.29^{\mathrm{ab}}$ & $3.78^{\mathrm{b}-\mathrm{d}}$ \\
G2 & $17.14^{\mathrm{a}-\mathrm{d}}$ & $3.80^{\mathrm{b}-\mathrm{e}}$ & 0.87 & $20.83^{\mathrm{fg}}$ & $1.65^{\mathrm{f}}$ \\
G3 & $16.18^{\mathrm{c}-\mathrm{e}}$ & $4.31^{\mathrm{a}-\mathrm{d}}$ & 4.68 & $23.02^{\mathrm{cd}}$ & $3.11^{\mathrm{b}-\mathrm{f}}$ \\
G4 & $14.96^{\mathrm{e}}$ & $4.24^{\mathrm{a}-\mathrm{d}}$ & 0.78 & $23.48^{\mathrm{a}-\mathrm{c}}$ & $3.43^{\mathrm{b}-\mathrm{e}}$ \\
G5 & $15.05^{\mathrm{de}}$ & $4.19^{\mathrm{a}-\mathrm{d}}$ & 0.80 & $19.90^{\mathrm{gh}}$ & $2.32^{\mathrm{d}-\mathrm{f}}$ \\
G6 & $15.01^{\mathrm{e}}$ & $4.34^{\mathrm{a}-\mathrm{d}}$ & 0.88 & $20.46^{\mathrm{fg}}$ & $3.40^{\mathrm{b}-\mathrm{e}}$ \\
G7 & $16.53^{\mathrm{b}-\mathrm{e}}$ & $4.31^{\mathrm{a}-\mathrm{d}}$ & 0.78 & $22.26^{\mathrm{de}}$ & $3.21^{\mathrm{b}-\mathrm{e}}$ \\
G8 & $16.24^{\mathrm{c}-\mathrm{e}}$ & $4.09^{\mathrm{a}-\mathrm{e}}$ & 0.66 & $19.24^{\mathrm{h}}$ & $3.11^{\mathrm{b}-\mathrm{f}}$ \\
G9 & $17.47^{\mathrm{a}-\mathrm{c}}$ & $4.44^{\mathrm{a}-\mathrm{c}}$ & 0.71 & $23.30^{\mathrm{b}-\mathrm{d}}$ & $3.01^{\mathrm{c}-\mathrm{f}}$ \\
G10 & $17.46^{\mathrm{a}-\mathrm{c}}$ & $4.76^{\mathrm{a}}$ & 1.32 & $21.41^{\mathrm{ef}}$ & $2.07^{\mathrm{ef}}$ \\
G11 & $15.51^{\mathrm{c}-\mathrm{e}}$ & $4.55^{\mathrm{a}-\mathrm{c}}$ & 1.19 & $21.31^{\mathrm{ef}}$ & $4.62^{\mathrm{b}}$ \\
T1 & $15.17^{\mathrm{de}}$ & $3.76^{\mathrm{b}-\mathrm{e}}$ & 0.91 & $20.91^{\mathrm{fg}}$ & $3.15^{\mathrm{b}-\mathrm{f}}$ \\
T2 & $17.16^{\mathrm{a}-\mathrm{d}}$ & $3.71^{\mathrm{c}-\mathrm{e}}$ & 1.28 & $20.81^{\mathrm{fg}}$ & $2.85^{\mathrm{c}-\mathrm{f}}$ \\
T3 & $14.82^{\mathrm{e}}$ & $3.52^{\mathrm{de}}$ & 1.05 & $20.32^{\mathrm{f}-\mathrm{h}}$ & $4.31^{\mathrm{bc}}$ \\
T4 & $16.35^{\mathrm{b}-\mathrm{e}}$ & $4.13^{\mathrm{a}-\mathrm{d}}$ & 0.75 & $19.87^{\mathrm{gh}}$ & $3.79^{\mathrm{b}-\mathrm{d}}$ \\
C1 & $16.73^{\mathrm{b}-\mathrm{e}}$ & $3.24^{\mathrm{e}}$ & 0.95 & $22.17^{\mathrm{de}}$ & $4.04^{\mathrm{bc}}$ \\
C2 & $15.91^{\mathrm{c}-\mathrm{e}}$ & $3.49^{\mathrm{de}}$ & 0.88 & $19.82^{\mathrm{gh}}$ & $2.86^{\mathrm{c}-\mathrm{f}}$ \\
C3 & $18.87^{\mathrm{a}}$ & $4.61^{\mathrm{ab}}$ & 0.94 & $23.22^{\mathrm{b}-\mathrm{d}}$ & $7.11^{\mathrm{a}}$ \\
C4 & $16.69^{\mathrm{b}-\mathrm{e}}$ & $3.79^{\mathrm{b}-\mathrm{e}}$ & 0.93 & $24.45^{\mathrm{a}}$ & $3.79^{\mathrm{b}-\mathrm{d}}$ \\
C5 & $15.18^{\mathrm{de}}$ & $4.22^{\mathrm{a}-\mathrm{d}}$ & 0.95 & $19.94^{\mathrm{gh}}$ & $3.91^{\mathrm{bc}}$ \\
\hline N & &
\end{tabular}

Note: The numbers in the same column followed by the same letter are not significantly different in the HSD Test at a significant level of $5 \%$
Table 4. Tolerance of 20 cowpea genotypes against A. craccivora infestation

\begin{tabular}{|c|c|c|c|}
\hline \multirow{2}{*}{ Genotype } & \multicolumn{2}{|c|}{ Amount of aphids* } & \multirow{2}{*}{$\begin{array}{l}\text { \% Decreases of } \\
\text { dry weight* }\end{array}$} \\
\hline & Aptera & Classifications** & \\
\hline G1 & $125.33^{\mathrm{b}-\mathrm{e}}$ & Very high & $46.96^{\mathrm{a}-\mathrm{c}}$ \\
\hline G2 & $117.33^{\mathrm{b}-\mathrm{e}}$ & Very high & $22.87^{\mathrm{a}-\mathrm{c}}$ \\
\hline G3 & $166.33^{\mathrm{a}-\mathrm{c}}$ & Very high & $51.83^{\mathrm{a}}$ \\
\hline G4 & $112.33^{\mathrm{b}-\mathrm{e}}$ & Very high & $11.06^{\mathrm{bc}}$ \\
\hline G5 & $86.00^{\mathrm{e}}$ & High & $26.61^{a-c}$ \\
\hline G6 & $119.33^{\mathrm{b}-\mathrm{e}}$ & Very high & $32.05^{\mathrm{a}-\mathrm{c}}$ \\
\hline G7 & $122.00^{\mathrm{b}-\mathrm{e}}$ & Very high & $34.49^{a-c}$ \\
\hline G8 & $149.00^{\mathrm{a}-\mathrm{d}}$ & Very high & $27.81^{\mathrm{a}-\mathrm{c}}$ \\
\hline G9 & $102.33^{\mathrm{de}}$ & Very high & $36.07^{\mathrm{a}-\mathrm{c}}$ \\
\hline G10 & $148.33^{\mathrm{a}-\mathrm{d}}$ & Very high & $21.33^{\mathrm{a}-\mathrm{c}}$ \\
\hline G11 & $78.33^{\mathrm{e}}$ & High & $33.14^{\mathrm{a}-\mathrm{c}}$ \\
\hline $\mathrm{T} 1$ & $109.00^{c-e}$ & Very high & $31.98^{\mathrm{a}-\mathrm{c}}$ \\
\hline $\mathrm{T} 2$ & $90.67^{\mathrm{de}}$ & High & $38.44^{\mathrm{a}-\mathrm{c}}$ \\
\hline T3 & $173.00^{\mathrm{ab}}$ & Very high & $36.25^{\mathrm{a}-\mathrm{c}}$ \\
\hline $\mathrm{T} 4$ & $67.00^{\mathrm{e}}$ & Medium high & $8.83^{c}$ \\
\hline $\mathrm{C} 1$ & $100.33^{\mathrm{de}}$ & Very high & $35.40^{\mathrm{a}-\mathrm{c}}$ \\
\hline $\mathrm{C} 2$ & $188.33^{\mathrm{a}}$ & Very high & $35.52^{\mathrm{a}-\mathrm{c}}$ \\
\hline C3 & $81.00^{\mathrm{e}}$ & High & $21.63^{\mathrm{a}-\mathrm{c}}$ \\
\hline $\mathrm{C} 4$ & $125.00^{\mathrm{b}-\mathrm{e}}$ & Very high & $41.77^{\mathrm{a}-\mathrm{c}}$ \\
\hline C5 & $97.67^{\mathrm{de}}$ & Very high & $40.69^{a-c}$ \\
\hline
\end{tabular}

Notes: * Investment time of A. craccivora 5 days with 5 adult aphids; ** Classification of the severity of aphids attack follows (Daryanto et al. 2017) 


\section{Discussion}

Characterization is important in determining the direction of utilization of cowpea. Based on this study, we evaluate morpho-agronomy performance, seed nutrition content, and resistance of cowpea genotypes to Aphis craccivora and also, we know there are several advance cross-breed and screening genotypes with unique morphology of pod and seed characters, a superior character in yield character, and there is genotype that had resistance character to A. craccivora.

Based on this research, it is known that the color of the genotypes of pods F4-002TG2-5-1 (G2), F6-002TG2-5-32-B (G7), KTH-2-2-2 (G9), KTH-2-5 -11 (G10), and KTH2-6-1-9 (G11) are purplish red to purple, according to Koley et al. (2019) explained that the purple color of the pea pods indicates the high content of antioxidants contained. Furthermore, according to Wang et al. (2011), the antioxidant content in this food is good in reducing the risk of cardiovascular disease. Therefore, the utilization of these genotypes is good when young pods are harvested and then used as vegetable commodities. Meanwhile, genotype F6-002004-8-1-B-3 (G5) has a unique seed color character, which has a white/beige seed coat color that can be developed as a raw material for making tempeh a substitute for soybeans. This is in accordance with the statement of Bahar and Witono (2015) that cowpeas can be used as raw material for tempeh, and according to Haliza et al. (2007), cowpea tempeh has a fairly high protein content and is low in fat with every $100 \mathrm{~g}$ of cowpea tempeh containing $33 \mathrm{~g}$ protein, $2 \mathrm{~g}$ fat, $53 \mathrm{~g}$ carbohydrates, $3 \mathrm{~g}$ fiber, and $1 \mathrm{~g}$ ash.

Other agronomic variables that also need to be considered are pod length, number of seeds per pod, and yield productivity of both young and dry pods. The crossbreeding genotypes showed improvement in character values on the pod length variables, which were G7 (F6002TG2-5-3-2-B), G2 (F4-002TG2-5-1), and G9 (KTH-22- 2) had a higher median value of pod length than the parents and the comparison variety, while on the variable number of seeds per pod, the test genotypes and the crossed parents had a lower mean value than the comparison variety. In addition, the nutritional content of dry cowpea seeds that have been evaluated through the proximate analysis method showed that the 20 test genotypes had protein content ranging from $19 \%$ to $25 \%$, whereas several genotypes derived from crosses showed an improvement in protein content around $3.8 \%$ to $18.5 \%$.

According to Acquaah (2012), the estimated heritability values for several plants, pod length, and the number of seeds per pod were 67\% (high) and 30\% (medium). However, based on the research of Chaudhary et al. (2020) on cowpea plants, heritability values in the broad sense for the variables of pod length and the number of seeds per pod had values of $87.26 \%$ and $77.53 \%$, respectively, which were classified as high heritability values based on the classification of Nkhoma et al. (2020) which classified heritability values into several categories which are low (0$30 \%)$, moderate $(30-60 \%)$, and high $(>60 \%)$. This shows that the pod length and the number of seeds per pod are largely influenced by the inheritance of the two parent's characters.

Character improvement is formed from the result of crossing (hybridizing) two parents of the cross. The hybridization process was carried out to combine characters from two genetically different parents. According to Purnamasari et al. (2019), the characteristics of yield components inherited additively in cowpea include the number of seeds per pod, number of pods per plant, length of young pods, and length of old pods, yield per plant, and protein content of seeds. The inheritance pattern in the characters controlled by these additive genes causes genotypes that have the same characteristics as their superior parents or even superior to their parents.

In addition to the agronomic character, resistance to certain pests is very necessary because cowpea cultivation activities experience various obstacles as in other food commodities. According to Nkomo et al. (2021), insect pests, diseases (fungi, viruses, and bacteria), poor soil fertility, metal poisoning, and drought can potentially reduce cowpea yields. This is supported by Obopile and Ositile (2010), cowpea aphids, Aphis craccivora are polyphagous pests on cowpea plants that attack all parts of the plant and cause significant yield losses. According to Togola et al. (2017), host plant resistance is an environmentally friendly, cost-effective, and sustainable pest management option to minimize pest incidence and severity.

According to Soffan and Aldawood (2014), some differences in the quality of host plants based on cultivar differences are caused by genetic variations, and environmental influences can also determine the growth and development of cowpea aphids. According to Daryanto et al. (2017), the optimal environment for the growth of aphids ranged at a temperature of $28 \pm 2^{\circ} \mathrm{C}$ with a humidity of $65 \pm 10 \%$. Based on the research of Deschamps et al. (2015), in alfalfa plants, a decrease in plant dry weight due to $A$. craccivora infestation reduces plant dry weight by 10 $26 \%$. While in the research of Laamari et al. (2008), A. craccivora infestation caused an $8 \%$ to $38 \%$ reduction in plant dry weight. Based on this study, it can be seen that the genotypes that have a fairly good resistance at five days of infestation are TG-2 (T1), F6-002TG2-5-1-S (G4), KTH 2-5-11 (G10), KT-5 (C3), F4-002TG2-5-1 (G2), F6002004-8-1-B-3 (G5), and F6-004002-7-B-9 (G8) with levels damage below $30 \%$.

Thus it can be concluded that there are three genotypes of cowpea that have the best yield component agronomic characters, namely, F4-002001-11-B (G1), F6-004002-7-B9 (G8), and F6-002004-8- 1-B-3 (G5). Genotype F4002001-11-B (G1) with green pod color and white-black seed color with high productivity of young pods, so it is potential as a cowpea cultivar as a source of fiber by harvesting in the young pod phase. Genotype F6-002004-81-B-3 (G5) with white/beige seed color has the potential to be used as a raw material commodity for the tempe industry, besides that it has good resistance to $A$. craccivora pests. Genotypes F4-002TG2-5-1 (G2) and KTH-2-5-11 (G10) had purplish-red to purple pods that were potential with good resistance to attack by $A$. craccivora. 


\section{ACKNOWLEDGEMENTS}

Thank you to the Ministry of Research and Technology/BRIN, Jakarta, Indonesia, for funding this research in the 2020 Budget through the Applied Research Grant by Muhamad Syukur.

\section{REFERENCES}

Acquaah G. 2012. Principles of Plant Genetics and Breeding. 2 ${ }^{\text {nd }}$ Ed Wiley-Blackwell, Maryland.

Avanza M, Acevedo B, Chaves M, Añón M. 2013. Nutritional and antinutritional components of four cowpea varieties under thermal treatments: Principal component analysis. LWT Food Sci Technol 51 (1): 148-157. DOI: 10.1016/j.lwt.2012.09.010

Bahar A, Witono Y. 2015. Process optimization of tempeh protein isolate from soybean (Glycine max Merr) and cowpea (Vigna unguiculata) mixture. Intl J Adv Sci Eng Inf Technol 5 (2): 139-143. DOI: 10.18517/ijaseit.5.2.501

Balitkabi. 2016. Description of Cowpea Superior Varieties 1991-1998 Balai Penelitian Tanaman Aneka Kacang dan Umbih, Malang.

Boukar O, Bhattacharjee R, Fatokun C, Kumar P, Gueye B. 2013. Cowpea. In: Singh M, Upadhyaya HD, Bisht IS (eds). Genetic and Genomic Resources of Grain Legume Improvement. Elsevier, London.

Budhi GS, Aminah M. 2010. Swasembada kedelai: Antara harapan dan kenyataan. Forum Peneliti Agro Ekonomi 28 (1): 55-68. [Indonesia]

Chaudhary AR, Solanki SD, Rahevar PM, Patel DA. 2020. Genetic variability, correlation and path coefficient analysis for yield and its attributing traits in cowpea [Vigna unguiculata (L.) Walp] accessions. Intl J Curr Microbiol Appl Sci 9 (2): 1281-1293. DOI: 10.20546/ijcmas.2020.902.151

Daryanto A, Syukur M, Hidayat P, Maharijaya A. 2017. Antixenosis and antibiosis based resistance of chili pepper to melon aphid. J Appl Hortic 19 (2): 147-151. DOI: 10.37855/jah.2017.v19i02.27.

Deschamps L, Sánchez-chopa C, Bizet-turovsky J. 2015. Resistance in alfalfa to Aphis craccivora Koch. Chil J Agric Res 75 (4): 451-456. DOI: $10.4067 /$ S0718-58392015000500010

Ehlers JD, Hall AE. 1997. Cowpea (Vigna unguiculata L. Walp.). Field Crops Res 53: 187-204

Ginting E, Antarlina SS, Widowati S. 2009. Varietas unggul kedelai untuk bahan baku industri pangan. Jurnal Litbang Pertanian 28 (3): 79-87. [Indonesia]

Gomes AMF, Draper D, Nhantumbo N, Massinga R, Ramalho JC, Marques I, Ribeiro-Barros AI. 2021. Diversity of cowpea [Vigna unguiculata (L.) walp] landraces in Mozambique: New opportunities for crop improvement and future breeding programs. Agronomy 11 (5): 991. DOI: 10.3390/agronomy11050991.

Haliza W, Purwani E, Thahir R. 2007. Pemanfaatan kacang-kacangan lokal sebagai substitusi bahan baku tempe dan tahu. Buletin Teknologi Pascapanen Pertanian 3 (1): 1-8.

Himawati E. 2019. Differences in Performance and Yield of Cowpea Genotype F4 Generation (Vigna unguiculata (L.) Walp. subsp. unguiculata). [Thesis]. Institut Pertanian Bogor, Indonesia. [Indonesian]

Horn LN, Shimelis H. 2020. Production constraints and breeding approaches for cowpea improvement for drought-prone agroecologies in Sub-Saharan Africa. Ann Agric Sci 65 (1): 83-91. DOI: 10.1016/j.aoas.2020.03.002
James CK, Perry KL. 2004. Transmission of plant viruses by aphid vectors. Mol Plant Pathol 5 (5): 505-511. DOI: 10.1111/j.13643703.2004.00240.x

Kirigia D, Winkelmann T, Kasili R, Mibus H. 2018. Development stage, storage temperature and storage duration influence phytonutrient content in cowpea (Vigna unguiculata L. Walp.). Heliyon 4 (6): 1-24. DOI: 10.1016/j.heliyon.2018.e00656

Koley TK, Maurya A, Tripathi A, Singh BK, Singh M, Bhutia TL, Tripathi PC, Singh B. 2019. Antioxidant potential of commonly consumed underutilized leguminous vegetables. Intl J Veg Sci 25 (4): 362-372. DOI: 10.1080/19315260.2018.1519866

Laamari M, Khelfa L, Coeur d'Acier A. 2008. Resistance source to cowpea aphid (Aphis craccivora Koch) in broad bean (Vicia faba L.) Algerian landrace collection. Afr J Biotechnol 7 (14): 2486-2490.

Mbeyagala EK, Mukasa BS, Tukamuhabwa P, Bisikwa J. 2014. Evaluation of cowpea genotypes for virus resistance under natural conditions in Uganda. J Agric Sci 6 (10): 176-187. DOI: 10.5539/jas.v6n10p176

Narayana M, Angamuthu M. 2021. Cowpea. In: Pratap A, Gupta S (eds). The Beans and the Peas. Elsevier, Netherlands.

Nkhoma N, Shimelis H, Laing MD, Shayanowako A, Mathew I. 2020. Assessing the genetic diversity of cowpea [Vigna unguiculata (L.) Walp.] germplasm collections using phenotypic traits and SNP markers. BMC Genet 21 (1): 110. DOI: 10.1186/s12863-020-00914-7

Nkomo GV, Sedibe MM, Mofokeng MA. 2021. Production constraints and improvement strategies of cowpea (Vigna unguiculata L. Walp.) genotypes for drought tolerance. Intl J Agron 2021: 5536417. DOI: $10.1155 / 2021 / 5536417$

Obopile M, Ositile B. 2010. Life table and population parameters of cowpea aphid, Aphis craccivora Koch (Homoptera: Aphididae) on five cowpea (Vigna unguiculata (L.) Walp.) varieties. J Pest Sci 83 (1): 9-14. DOI: 10.1007/s10340-009-0262-0

Purnamasari I, Sobir S, Syukur M. 2019. Diversity and inheritance in cowpea (Vigna unguiculata) on protein and yield components $\begin{array}{llll}\text { characters. Biodiversitas } 20 & \text { (5): 1294-1298. DOI: }\end{array}$ 10.13057/biodiv/d200507

Sahid ZD, Syukur M, Maharijaya A. 2020. Combining ability and heterotic effects of chili pepper (Capsicum annuum L.) genotypes for yield components and capsaicin content. SABRAO J Breed Genet 52 (4): 390-401.

Setyowati M, Sutoro S. 2010. Evaluasi plasma nutfah kacang tunggak (Vigna unguiculata L.) di lahan masam. Buletin Plasma Nutfah 16 (1): 44-48. DOI: 10.21082/blpn.v16n1.2010.p44-48

Soffan A, Aldawood AS. 2014. Biology and demographic growth parameters of cowpea aphid (Aphis craccivora) on faba bean (Vicia faba) cultivars. J Insect Sci 14 (120): 1-10. DOI: 10.1673/031.014.120.

Srinivas J, Kale VS, Nagre PK. 2017. Correlation and path analysis study in cowpea [Vigna unguiculata (L.) Walp.] genotypes. Intl J Curr Microbiol Appl Sci 6 (6): 3305-3313. DOI: 10.20546/ijcmas.2017.606.388.

Togola A, Boukar O, Belko N, Chamarthi SK, Fatokun C, Tamo M, et al. 2017. Host plant resistance to insect pests of cowpea (Vigna unguiculata L. Walp.): achievements and future prospects. Euphytica 213, 239. 10.1007/s10681-017-2030-1.

Trustinah T. 2015. Cowpea is a potential commodity in acidic dry land. Info Teknologi. [Indonesian]

Wang S, Melnyk JP, Tsao R, Marcone MF. 2011. How natural dietary antioxidants in fruits, vegetables and legumes promote vascular health. Food Res Intl 44 (1): 14-22. DOI: 10.1016/j.foodres.2010.09.028. 